\title{
Functional Listening Performance of Sequential Bilateral Cochlear Implantation in Young Adults with Congenital Deafness
}

\author{
Youngmee Lee \\ Department of Communication Disorders, Tongmyong University, Busan, Korea
}

Correspondence: Youngmee Lee, PhD Department of Communication Disorders, Tongmyong University, 428 Sinseon-ro, Nam-gu, Busan 48520, Korea

Tel: $+82-51-629-2135$

Fax: +82-51-629-2019

E-mail: ymlee3060@gmail.com

Received: October 19, 2018

Revised: November 12, 2018

Accepted: November 26, 2018

This research was supported by the Tongmyong University of Research Grants 2018 (No 2018F063).

\begin{abstract}
Objectives: This study aimed to evaluate the functional benefits of young adults with bilateral cochlear implants $(\mathrm{Cls})$ in comparison with those with unilateral $\mathrm{Cls}$ and those with normal hearing $(\mathrm{NH})$, to assess whether demographic and performance factors can predict the functional listening performance for each $\mathrm{Cl}$ group, and to examine the predictors of functional listening performance for bilateral and unilateral $\mathrm{Cl}$ groups. Methods: Fifteen young adults with sequential bilateral $\mathrm{Cls}$, 15 adults with unilateral $\mathrm{Cls}$, and 15 adults with $\mathrm{NH}$ participated in this study. The functional listening performance in daily life was measured using the Speech, Spatial, and Qualities of hearing scale (SSQ). Results: Adults with bilateral Cls showed significantly better performance in all three sections (speech perception, spatial hearing, other qualities of hearing) than those with unilateral $\mathrm{Cls}$, although they showed significantly poorer performance than those with $\mathrm{NH}$ on the SSQ. In the unilateral $\mathrm{Cl}$ group, speech perception and receptive vocabulary scores contributed significant amount to the functional listening performance. In the logistic regression analysis, the rating of other qualities of hearing was a significant predictor for differentiating between the bilateral and unilateral $\mathrm{Cl}$ group. Conclusion: Young adults who received sequential bilateral cochlear implantation achieved functional binaural benefits in daily life. These results were vital in counseling adolescents, young adults, and their families to make decisions regarding the second implantation.
\end{abstract}

Keywords: Functional listening performance, Sequential bilateral cochlear implantation, Young adults, Congenital deafness 인공와우이식(cochlear implantation)이 고도 이상의 청각장애 인에게 유용한 청력을 제공하는 재활방법으로 자리매김하였지만, 소음 조건에서의 말지각(speech perception)과 소리 방향성(sound localization)에서의 일측 인공와우이식의 한계를 극복하고자 2000 년대 중반부터는 국내에는 양측 인공와우이식에 대한 관심이 높아 지기 시작하였다. 2009년부터 양측 인공와우이식에 대한 국내 건 강의료보험의 적용범위가 아동과 청소년에게 확대되면서, 양측 인 공와우이식에 대한 관심이 더욱 높아지게 되었다(Kim, Kim, \& Jeong, 2013; Korea Ministry for Health \& Welfare and Family Affairs, 2009). 양측 인공와우이식은 두 귀의 인공와우이식이 시행되 는 수술 시점에 따라서 동시적 인공와우이식(simultaneous cochle- ar implantation)과 순차적 인공와우이식(sequential cochlear implantation)으로 구분된다(Papsin \& Gordon, 2008). 동시적 양측 인공와우이식은 양 귀에 인공와우이식을 동시에 시행하는 것이며, 순차적 양측 인공와우이식은 양 귀에 인공와우이식을 시간 간격을 두고 시행하는 것을 말한다. 동시적 양측 인공와우이식의 경우, 비 용 절감뿐만 아니라 듣기, 말, 언어 발달 측면에서 일측 인공와우이 식에 비해 효과가 크다고 보고되면서, 고도 이상의 청각장애 영유 아를 대상으로 동시적 양측 인공와우이식이 시행되고 있다(Long et al., 2018).

청각장애인은 일측 인공와우만을 착용할 때보다 양측 인공와우 착용을 통해서 소리 방향 분별력과 소음 조건에서의 말지각 검사에 
서 더 높은 수행력을 보이는 것으로 알려져 있다(Kühn-Inacker, Shehata-Dieler, Müller, \& Helms, 2004; Lee \& Sim, 2015; Noble, Tyler, Dunn, \& Bhullar, 2009; Nopp, Schleich, \& D’Haese, 2004; Papsin \& Gordon, 2008; Tyler, Dunn, Witt, \& Noble, 2007). Nopp 등(2004)이 양측 인공와우이식 성인을 대상으로 $22.5^{\circ}$ 간격으로 9 개의 스피커를 설치하여 방향 분별력 검사를 실시한 결과, 자극이 제시된 스피커의 방위각과 대상자가 반응한 스피커의 방위각 간의 평균 편차가 일측 인공와우를 착용한 상태에서는 $37.15^{\circ}$, 양측 인공 와우를 착용한 상태에서는 $16.6^{\circ}$ 로 나타나서, 방향 분별의 오류 각 도가 일측보다는 양측 인공와우를 착용한 상태에서 유의하게 감소 하였다. Tyler 등(2007)이 양측 인공와우이식 성인을 대상으로 일 측과 양측 인공와우 착용 상태에서의 소리 방향 분별력과 소음 조 건에서의 말지각 검사를 실시한 결과, 대상자의 상당수가 양측 인 공와우를 착용한 상태에서 소리 방향 분별력과 말지각 모두 향상 되었다. 또한, Strøm-Roum, Laurent와 Wie (2012)는 양측 인공와 우이식은 청각장애인이 일측 인공와우만을 착용할 때보다 더 자연 스러운 말소리를 들을 수 있게 하고, 소음 조건에서의 다양한 대화 상황에서 듣기에 들이는 노력을 최소화하여 의사소통 자신감을 향상시키는 데도 도움을 줄수 있다고 언급하였다.

선행연구(Kühn-Inacker et al., 2004; Noble et al., 2009; Nopp et al., 2004; Papsin \& Gordon, 2008; Tyler et al., 2007)에서 보고된 바 와 같이, 방향 분별력과 말지각 측면에서 청각장애인이 양측 인공 와우이식을 통해 얻을 수 있는 듣기 이득은 명확하지만, 그 이득의 정도는 청각장애와 관련된 변인(예: 청각장애 발생시기, 양측 인공 와우이식 연령 등)에 따라서 개인 간 차이가 큰 것으로 알려져 있다 (Galvin, Hughes, \& Mok, 2010; Santarelli, De Filippi, Genovese, \& Arslan, 2008). 무엇보다 양측 인공와우이식은 선천성 농 영유아, 아동, 청소년, 그리고 청각장애 원인 및 발생시기가 다양한 성인에 이르기까지 이질적인 집단(heterogeneous group)에 시행되기 때문 에, 대상자 특성에 따라서 청력검사실과 같은 구조화된 장소에서 실시하는 방향 분별력과 말지각 검사를 통해 양측 인공와우이식의 듣기 이득을 실제적으로 측정하는 데 한계가 있을 수 있다. 예를 들 면, 청각장애인이 본인이나 가족이 양측 인공와우를 통해 일상생 활에서 듣기 수행력이 향상되었다고 주관적으로 보고하더라도, 실 제 공식검사에서의 점수 변화는 거의 나타나지 않을 수 있는 것이 다. 무엇보다 상당수의 일측 인공와우이식 아동 및 성인은 일상생 활에서의 실제적인 듣기 이득을 얻기 위해서 양측 인공와우이식을 선택하기 때문에, 청력검사실에서 진행되는 공식검사 외에도 기능 적인 듣기 수행력을 측정하는 것은 매우 중요하다고 할 수 있다.

양측 인공와우이식의 효과를 측정하기 위해서 시행하는 방향
분별력과 말지각 검사의 한계를 극복하고 기능적인 듣기 수행력을 평가하고자 Gatehouse와 Noble (2004)이 청각장애인이 일상생활 에서 실제로 경험하는 다양한 듣기 시나리오를 토대로 언어 공간 음질 청취 평가(The Speech, Spatial and Qualities of Hearing Scale, $\mathrm{SSQ}$ ) 설문지를 개발하였다.SSQ 설문지가 개발되기 전에도 청각장 애인이 일상생활에서 주관적으로 지각하는 듣기 능력 및 어려움을 평가하고자 Abbreviated Profile of Hearing and Benefit (APHAB; Cox \& Alexander, 1995), Client Oriented Scale of Improvement (COSI; Dillon, James, \& Ginis, 1997), International Outcome Inventory for Hearing Aids (IOI-HA; Cox \& Alexander, 2002) 등이 개발되어 임상현장 및 연구 분야에서 사용되고 있다. 하지만, 이러 한 검사의 문항은 보청기를 착용한 청각장애 성인의 주관적 만족 도와 이득에 초점을 맞추어 개발되었기 때문에, 양측 인공와우이 식 성인, 인공와우와 보청기를 착용하는 성인의 양이 청취 이득을 측정하기에는 한계가 있었다. $\mathrm{SSQ}$ 는 언어, 공간, 음질 측면에서 양 이 청취와 관련한 문항이 개발되었으며, 단순히 청력검사의 역치만 으로 청각장애 정도를 판단하는 것에서 탈피하여 일상생활에서 청 각장애인이 경험하는 듣기 어려움의 정도를 종합적으로 파악할 수 있는 장점을 지니고 있다. 이러한 이유로 청각재활전문가와 연구자 에게 SSQ는 양측 인공와우 이식의 이득을 평가하는 데 유용한 검 사도구로 여겨지며, 국내외에서 임상적 평가와 연구 목적으로 다양 한 연령대의 양측 인공와우이식 대상자의 기능적 듣기 수행력을 평 가하는 데 사용되고 있다(Galvin et al., 2010; Kim et al., 2013; Kim et al., 2015; Noble et al., 2009).

현재 국내에는 신생아청각선별검사의 시행으로 청각장애의 진 단뿐만 아니라 청각재활도 조기에 가능한 실정이다. 하지만, 양측 귀의 청력손실 정도가 $90 \mathrm{~dB}$ 이상의 20-30대 농 청년의 경우, 난청 전문 프로그램의 미비, 신생아청각선별검사의 미시행, 인공와우이 식 및 청각재활서비스 비용에 대한 국가적 지원의 부재, 인공와우 이식센터 및 청각재활전문기관의 수가 부족한 시기에 아동기를 보 낸 세대에 해당된다. 이들은 인공와우이식에 대한 비용 부담, 인공 와우이식에 대한 부정적인 인식 등의 다양한 개인적인 이유로 어린 연령에 인공와우이식을 받지 못하였거나 인공와우이식을 받았더 라도 정상적인 말, 언어 발달을 위한 완전한 청각 재활을 제대로 받 지 못한 경우가 상당히 포함되어 있다(Heo \& Kim, 2010; Huh \& Lee, 2009). 이러한 이유로 인공와우이식 청년은 대인관계에서 중요 한 의사소통에 어려움을 경험하며, 청년기의 주요 이슈인 진로와 취업에서 정상청력 청년에 비해 더 많은 제약에 직면하게 된다. 최 근 국내에서 발표된 인공와우이식 청년과 관련된 연구(Choi, Kim, Jeong, \& Kim, 2017; Kim \& Yoon, 2017; Lee, Jung, Tark, Lee, \& Lee, 
2018)를 살펴보면, 인공와우이식 청년의 의사소통과 관련된 삶의 질(quality of communication life)과 대인관계 유능성(interpersonal competence)이 정상청력 청년에 비해서 낮으며, 듣기 능력과 말 명료도가 인공와우이식 청년의 삶의 질과 대인관계 유능성에 영향 을 미치는 요인으로 나타났다.

일측 인공와우이식 청소년과 청년은 일측 인공와우이식의 한계 를 지각하여 의사소통 관련 삶의 질 향상을 위해서 양측 인공와우 이식을 고려하기 시작하면서, 순차적으로 양측에 인공와우이식을 받는 청소년과 청년의 수가 증가하기 시작하였다. 즉, 아동기에 첫 번째 인공와우이식을 받고 성장한 청소년과 청년의 상당수가 성인 으로서 대인관계 형성, 진로 및 취업에서 겪는 의사소통 어려움을 해결하기 위해서 듣기 수행력의 향상이 필요하다고 인식하면서, 국 내외 인공와우이식 센터에서 일측 인공와우이식 청소년과 성인이 잠재적인 양측 인공와우이식 대상자로 고려되기 시작하였다(Galvin et al., 2010). 일측 인공와우이식 청소년과 청년은 인공와우 기 기를 스스로 관리하며 두 번째 인공와우이식을 본인 의지에 따라 결정한다는 측면에서, 부모에 의해서 양측 인공와우이식을 결정하 게 되는 어린 연령대의 청각장애 아동과는 다른 특징을 지닌다고 할 수 있다. 그러므로, 순차적으로 양측 인공와우이식을 시행받은 청년의 일상생활에서의 기능적인 듣기 수행력을 살펴봄으로써, 양 측 인공와우이식을 고려하고 있는 일측 인공와우이식 청소년과 청 년의 상담에 필요한 실제적인 정보를 청각재활전문가에게 제공할 수 있을 것이다. 이에 따라, 본 연구에서는 양측 인공와우이식을 순 차적으로 시행받은 청년의 기능적인 듣기 수행력을 살펴보기 위해 서, 일측 인공와우이식 청년, 양측 인공와우이식 청년, 정상청력 청 년의 기능적인 듣기 수행력을 듣기 항목(언어적 청취, 공간적 청취, 음질 청취)에 따라 비교 분석하였다. 그리고 인공와우이식 집단별 로 기능적인 듣기 수행력을 예측할 수 있는 변수를 살펴보았으며, 기능적 듣기의 하위 항목별 점수가 일측 인공와우이식 청년과 양 측 인공와우이식 청년을 구분하는 유의한 변수가 될 수 있는지를 살펴보았다. 이에 대한 구체적인 연구 질문은 다음과 같다.

첫째, 듣기 항목(언어적 청취, 공간적 청취, 음질 청취)과 집단(일 측 인공와우이식 청년, 양측 인공와우이식 청년, 정상청력 청년)에 따른 기능적 듣기 점수에 유의한 차이가 나타나는가?

둘째, 일측 인공와우이식 청년과 양측 인공와우이식 청년 집단 각각에서 단음절단어점수, 자음정확도, 수용어휘 점수 중에서 기 능적 듣기 점수를 예측하는 유의한 변수가 무엇인가?

셋째, 듣기 항목별(언어적 청취, 공간적 청취, 음질 청취) 점수 중 에서, 일측 인공와우이식 청년과 양측 인공와우이식 청년을 구분 할 수 있는 유의한 변수는 무엇인가?

\section{연구방법}

\section{연구대상}

본 연구에서는 일측 인공와우이식 청년(15명), 양측 인공와우이 식 청년(15명), 정상청력 청년(15명)을 대상으로 하였다. 일측 인공 와우이식 청년은 (1) 연령이 만 18세에서 28세 사이에 속하며, (2) 언 어습득 전 농(prelingual deafness)이며, (3) 아동기 혹은 청소년기 에 인공와우이식을 받았으며, (4) 와우 저형성(cochlear hypoplasia), 공동강 기형(common cavity)과 같은 심한 내이기형(severe inner ear malformations)이 없고, (5) 청각장애 외 중복장애(예, 지적장 애, 시각장애 등)가 없으며, (6) 구어 의사소통이 가능하며, (7) 읽기 문제를 동반하지 않는 대상자만으로 선정하였다. 양측 인공와우이 식 청년은 일측 인공와우이식 청년의 선정 기준과 동일하되, (1) 첫 번째와 두 번째 인공와우이식을 시간 간격을 두고 순차적으로 하 였으며, (2) 두 번째 인공와우 사용기간이 6개월 이상이며(Domviller-Lewis, Santa Maria, Upson, Chester-Browne, \& Atlas, 2015), (3) 양측 인공와우를 하루 종일 사용하는 대상자만으로 선정하였 다. 정상청력 청년은 (1) 연령이 만 18세에서 28세 사이에 속하며, (2) 청력검사(Interacoustics AD629, Assens, Denmark)에서 .5, 1, $2,4 \mathrm{kHz}$ 의 주파수에서 양측 모두 $20 \mathrm{~dB} \mathrm{HL}$ 이며, (3) 수용·표현어 휘력검사(Receptive \& Expressive Vocabulary Test, REVT; Kim, Hong, Kim, Jang, \& Lee, 2009)의 수용어휘 점수가 정상 범주에 속 한 대상자만을 선정하였다.

연구에 참여한 세 집단의 연령, 성별, 교육 수준, 인공와우이식 연 령, 인공와우 사용기간, 수용어휘 점수, 자음정확도, 단음절단어 점 수에 대한 기술통계 결과는 Table 1에 제시하였다. 생활연령, 인공 와우이식 연령, 수용어휘 점수, 자음정확도, 단음절단어 점수에 대 한 집단 간 동질성 검정을 위해 일원배치분산분석(one-way ANO$\mathrm{VA})$ 을 실시한 결과, 세 집단 간에 생활연령 $\left(F_{(2,44)}=.115, p=.891\right)$ 에 서는 유의한 차이가 없었다. 세 집단 간에 수용어휘 점수 $\left(F_{(2,44)}=\right.$ $6.083, p=.005)$ 에서는 유의한 차이가 있었으며, 정상청력 청년의 수용어휘 점수가 일측과 양측 인공와우이식 청년보다 유의하게 높 았다. 첫 번째 인공와우이식 연령 $\left(F_{(1,29)}=2.189, p=.150\right)$, 첫 번째 인 공와우 사용기간 $\left(F_{(1,29)}=3.356, p=.078\right)$, 자음정확도 $\left(F_{(1,29)}=.935\right.$, $p=.342)$ 에서는 일측과 양측 인공와우이식 집단 간에 유의한 차이 가 없었다. 단음절단어 점수에서는 두 집단 간에 유의한 차이가 있 었으며 $\left(F_{(1,29)}=5.419, p=.027\right)$, 양측 인공와우이식 청년의 단음절 단어 점수가 일측 인공와우이식 청년보다 높았다. 
Table 1. Characteristics of the participants

\begin{tabular}{|c|c|c|c|}
\hline & Unilateral $\mathrm{Cl}$ group $(\mathrm{N}=15)$ & Bilateral $\mathrm{Cl}$ group $(\mathrm{N}=15$ ) & $\mathrm{NH}$ group $(\mathrm{N}=15)$ \\
\hline Age (yr) & $20.9 \pm 1.3(18.3-23.1)$ & $21.3 \pm 2.5(18.1-27.0)$ & $21.2 \pm 1.9(18.6-24.5)$ \\
\hline \multicolumn{4}{|l|}{ Sex } \\
\hline Male & 6 & 6 & 7 \\
\hline Female & 9 & 9 & 8 \\
\hline \multicolumn{4}{|l|}{ Education status } \\
\hline University graduation & 0 & 5 & 3 \\
\hline College graduation & 1 & 3 & 0 \\
\hline University student & 14 & 7 & 12 \\
\hline College student & 0 & 0 & 0 \\
\hline Age of first Cl (yr) & $11.3 \pm 4.9(3.9-15.9)$ & $8.6 \pm 4.8(3.0-16.9)$ & \\
\hline Age of second $\mathrm{Cl}$ (yr) & & $16.3 \pm 7.4(9.6-24.9)$ & \\
\hline Duration of first $\mathrm{Cl}$ (yr) & $9.7 \pm 4.8(4.1-18.1)$ & $12.7 \pm 4.2(3.1-21.0)$ & \\
\hline Duration of second $\mathrm{Cl}(\mathrm{yr})$ & & $5.0 \pm 3.6(.6-11.2)$ & \\
\hline Receptive vocabulary scores ${ }^{\mathrm{a}}$ & $145.4 \pm 18.6(120-172)$ & $147.5 \pm 24.2(102-176)$ & $166.6 \pm 8.6(154-176)$ \\
\hline $\operatorname{PCC}^{b}(\%)$ & $87.9 \pm 9.6(70.0-100)$ & $91.2 \pm 8.9(67.0-100)$ & \\
\hline Word recognition scores ${ }^{\complement}(\%)$ & $65.8 \pm 25.9(20.0-96.0)$ & $83.1 \pm 12.5(54.0-96.0)$ & \\
\hline
\end{tabular}

Values are presented as mean $\pm \mathrm{SD}$ (range).

$\mathrm{Cl}=$ cochlear implant; $\mathrm{NH}=$ normal hearing; $\mathrm{PCC}=$ percentage of consonants correct.

aReceptive and Expressive Vocabulary Test-Receptive (Kim, Hong, Kim, Jang, \& Lee, 2009).

${ }^{b}$ Assessment of Phonology and Articulation for Children (Kim, Pae, \& Park, 2007).

'Korean Speech Audiometry for adults (Lee et al., 2010).

\section{연구도구}

본 연구에서는 대상자의 기능적 듣기 수행력을 평가하기 위해서 한국어판 언어공간음질청취평가(Korean version of the Speech, Spatial and Qualities of Hearing Scale, K-SSQ)를 이용하였다. 일 측과 양측 인공와우이식 청년의 집단 간 동질성 검정 실시와 기능 적 듣기 수행력에 영향을 미치는 변수를 탐색하기 위해서, 어음청 각검사(Korean Speech Audiometry, KSA; Lee et al., 2010)의 단음 절단어검사(일반용), 아동용 발음평가(Assessment of Phonology and Articulation for Children, APAC; Kim, Pae, \& Park, 2007), 수 용·표현어휘력검사(REVT; Kim et al., 2009)를 실시하였다.

\section{$\mathrm{K}-\mathrm{SSQ}$}

$\mathrm{SSQ}$ 는 청각장애인의 양이 청취(binaural hearing)의 이득을 평 가할 수 있도록 Gatehouse와 Noble에 의해서 2004년도에 개발되 었다(Gatehouse \& Noble, 2004). SSQ는 단순히 청력검사만으로 측 정할 수 없는 역동적인 듣기 환경 요소를 고려하여 문항이 개발되 어, 청각장애인의 듣기 어려움의 정도를 종합적으로 파악할 수 있 는 검사이다. SSQ는 일상생활에서의 듣기 능력을 평가할 수 있도 록 언어적 청취(speech perception, 14 문항), 공간적 청취(spatial hearing, 17문항), 음질 청취(qualities of hearing, 18문항)의 세 항목 으로 평가하며, 총 49 개 문항으로 구성되어 있다. 각 문항에 대한 응
답은 시각 아날로그 척도(visual analogue scale)에 따라 0점(전혀 아님)에서 10 점(완벽하게 그러함)으로 선택하도록 되어 있다. SSQ 는 처음에는 영어권에서 개발되어 사용되었으며, 현재는 프랑스어, 러시아어 등의 다양한 언어로 번안되고 타당도가 검증되어 사용되 고 있다. 처음에는 SSQ는 청각장애 성인을 대상으로 한 문항으로 만 개발되었으나 점차로 아동, 부모, 교사를 대상으로 실시할 수 있 도록 문항을 수정, 보완되어 적용 대상자가 확대되었다(Galvin \& Noble, 2013). 대한이과학회 설문지 번역회에서 청각장애 분야의 연구자 및 청각재활 전문가들이 SSQ를 한국어로 번역하고 신뢰도 와 타당도 검증에 겪는 어려움을 해결하기 위해서 $\mathrm{SSQ}$ 를 한국어 로 번안하였으며, 청각장애 성인 400 명을 대상으로 K-SSQ 설문조 사를 진행하여 신뢰도와 타당도를 검증하여 표준화된 K-SSQ를 2017년에 발표하였다(Kim et al., 2017) (Appendix 1).

\section{연구절차}

실험은 대학 임상센터 및 사설 언어치료실의 조용한 공간에서 대상자에게 개별적으로 실시하였다. 이때, 연구자는 대상자가 충분 한 시간 여유를 가지고 K-SSQ 문항에 응답할 수 있도록 시간 제한 을 두지 않았으며, 대상자가 문항에 대한 설명을 요청할 경우에는 문항을 정확하게 이해하고 응답할 수 있도록 충분히 설명하였다. 의사소통 관련 수행력 평가는 K-SSQ 설문이 진행된 공간에서 개 
별적으로 실시하였다. 말지각 검사는 KSA의 단음절단어검사를 이 용하여, 연구자가 보기가 없는 조건(open-set)에서 일상 대화 수준 의 말소리 강도인 60-70 dB SPL 수준으로 대상자에게 단음절단어 를 들려주었다. 말 산출은 APAC 단어수준 검사의 그림 자료를 대 상자에게 보여주고 그림에 해당하는 단어를 말하도록 하였다. 언어 이해는 REVT-R을 사용하였으며, 대상자가 제시된 네 개의 그림 중 에서 들려주는 단어에 해당하는 그림을 지적하도록 하였다. 수용 어휘 검사에서는 인공와우이식 청년이 말지각 오류로 단어를 잘못 지적하는 것을 방지하기 위해서, 대상자가 연구자의 발화를 독순 (lipreading)하는 것을 허용하였다.

\section{자료분석}

본 연구에서 K-SSQ 점수는 대상자가 응답한 시각 아날로그 점수 에 따라 문항당 1점에서 10점으로 채점하였으며, 언어적 청취(140 점), 공간적 청취(170점), 음질 청취(190점) 항목별 점수와 총점(490 점)은 백분율(\%)로 산출하였다. 듣기 항목에 따른 점수는 항목별 전체 점수에서 대상자의 응답 점수를 백분율(\%)로 산출하였으며, 총점은 총 점수에서 대상자의 세 항목에 대한 합산 점수를 백분율 (\%)로 산출하였다.

의사소통 수행력을 측정하기 위해서 실시한 검사를 살펴보면, $\mathrm{KSA}$ 의 단음절단어검사는 대상자가 정확하게 따라 말한 경우를 정 반응(1점), 그렇지 않은 경우를 오반응(0점)으로 채점하였고, 단음 절단어점수는 전체 단어수(50개)에서 대상자가 정확하게 따라 말 한 단어의 수를 백분율(\%)로 산출하였다. APAC에서 대상자가 정 조음한 음소를 정반응(1점), 오조음한 음소를 오반응(0점)으로 채 점하였으며, 자음정확도는 전체 음소 수(70개)에서 대상자가 정조 음한 음소 수를 백분율(\%)로 산출하였다. REVT-R에서는 대상자 가 목표단어에 해당하는 그림을 지적할 경우를 정반응(1점), 그렇 지 않은 경우를 오반응(0점)으로 채점하여, 수용어휘 점수를 원점

Table 2. K-SSQ scores of three groups according to three domains of the KSSO

\begin{tabular}{lccc}
\hline Domain & $\begin{array}{c}\text { Unilateral Cl group } \\
(\mathrm{N}=15)\end{array}$ & $\begin{array}{c}\text { Bilateral } \mathrm{Cl} \text { group } \\
(\mathrm{N}=15)\end{array}$ & $\begin{array}{c}\mathrm{NH} \text { group } \\
(\mathrm{N}=15)\end{array}$ \\
\hline $\begin{array}{c}\text { Speech perception } \\
(\%)\end{array}$ & $\begin{array}{c}48.76 \pm 31.29 \\
(25.00-74.29)\end{array}$ & $64.29 \pm 34.01$ & $84.86 \pm 9.05$ \\
$(31.43-83.57)$ & $(70.71-100)$ \\
Spatial hearing & $42.75 \pm 18.40$ & $52.55 \pm 20.01$ & $79.73 \pm 7.98$ \\
$(\%)$ & $(14.70-66.47)$ & $(14.71-85.88)$ & $(70.00-94.71)$ \\
Qualities of hearing & $50.26 \pm 16.78$ & $66.89 \pm 9.58$ & $86.44 \pm 9.19$ \\
$(\%)$ & $(19.44-85.00)$ & $(45.56-82.78)$ & $(71.11-98.89)$ \\
\hline
\end{tabular}

Values are presented as mean \pm SD (range).

$\mathrm{K}-\mathrm{SSQ}=$ Korean version of the Speech, Spatial and Qualities of Hearing Scale; $\mathrm{Cl}=$ cochlear implant; $\mathrm{NH}=$ normal hearing.
수로 산출하였다.

\section{자료의 통계적 처리}

본 연구에서는 IBM SPSS Statistics version 24 (IBM Co., Armonk, $\mathrm{NY}, \mathrm{USA}$ )를 이용하여 자료를 분석하였다. 첫째, 듣기 항목(언어적 청취, 공간적 청취, 음질 청취)과 집단(일측 인공와우이식 청년, 양 측 인공와우이식 청년, 정상청력 청년)에 따른 듣기 수행력의 차이 를 살펴보기 위해서, 이원 혼합분산분석(two-way mixed ANOVA) 을 실시하였다. 둘째, 인공와우이식 청년 각 집단에서 단음절단어 점수, 자음정확도, 수용어휘점수가 기능적 듣기 수행력에 유의한 영향을 미치는지 살펴보기 위해서, 단계적 중다회귀분석(stepwise multiple regression analysis)을 실시하였다. 마지막으로 K-SSQ의 세 항목(언어적 청취, 공간적 청취, 음질 청취)의 점수가 일측 인공 와우이식 청년과 양측 인공와우이식 청년을 구분하는 유의한 변 수인지 살펴보기 위해서, 이항 로지스틱 회귀분석(binary logistic regression analysis)을 실시하였다.

\section{연구결과}

\section{듣기 항목과 집단에 따른 기능적 듣기 수행력}

듣기 항목에 따른 일측 인공와우이식 청년, 양측 인공와우이식 청년, 정상청력 청년의 K-SSQ 점수에 대한 기술통계는 Table 2에 제시하였다.

집단에 따른 K-SSQ 점수에 대한 주효과가 유의하였으며 $\left(F_{(2,42)}=\right.$ $44.435, p=.000$, partial $\eta^{2}=.679$ ), 이에 따른 Bonferroni 사후검정 을 실시한 결과, 일측 인공와우이식 청년과 양측 인공와우이식 청

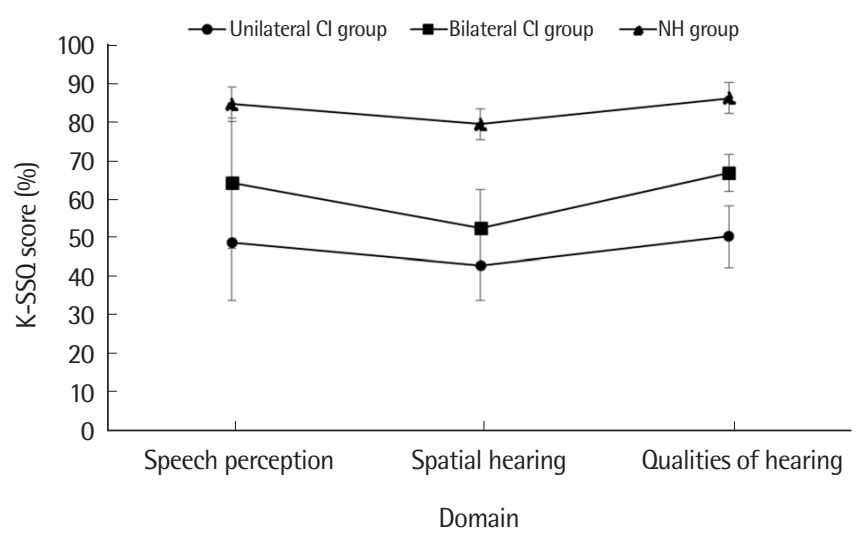

Figure 1. K-SSO scores of adults with unilateral $\mathrm{Cl}$, adults with bilateral $\mathrm{Cl}$, and adults with $\mathrm{NH}$ according to the three domains.

K-SSO = Korean version of the Speech, Spatial and Qualities of Hearing Scale; $\mathrm{Cl}=$ cochlear implant; $\mathrm{NH}=$ normal hearing. 
년 $(p=.002)$, 일측 인공와우이식 청년과 정상청력 청년 $(p=.000)$, 양측 인공와우이식 청년과 정상청력 청년 $(p=.002)$ 집단 간에 모두 유의한 차이가 있는 것으로 나타났다(Figure 1). 듣기 항목에 따른 K-SSQ 점수에 대한 주효과도 유의하였다 $\left(F_{(2,84)}=8.744, p=.000\right.$,

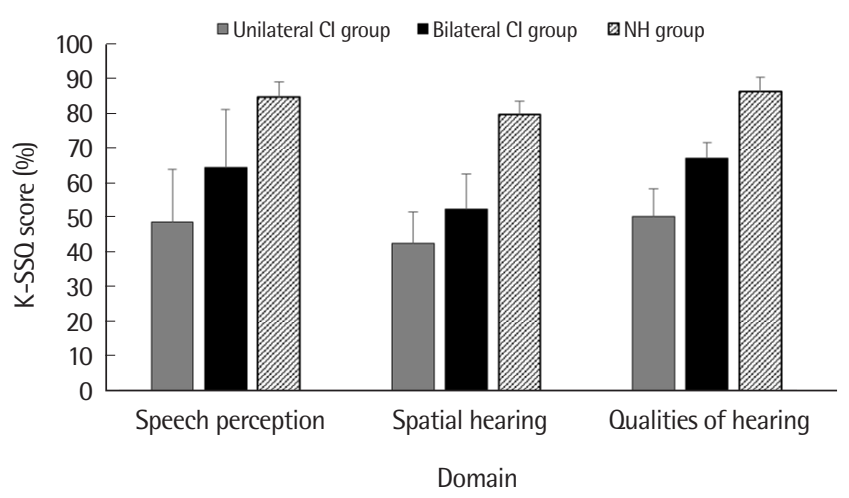

Figure 2. K-SSQ scores of the speech perception, spatial hearing, and qualities of hearing according to the three groups.

K-SSQ=Korean version of the Speech, Spatial and Qualities of Hearing Scale; $\mathrm{Cl}=$ cochlear implant; $\mathrm{NH}=$ normal hearing. partial $\left.\eta^{2}=.172\right)$. 듣기 항목 주효과에 대한 Bonferroni 사후검정을 실시한 결과, 언어적 청취와 음질 청취 $(p=.000)$, 공간적 청취와 음 질 청취 $(p=.000)$ 항목 간에 점수 차이가 유의하였다. 듣기 항목별 집단간차이를 살펴보기 위해서 일원배치분산분석(one-way ANO$\mathrm{VA})$ 을 실시한 결과, 언어적 청취와 음질 청취에서는 세 집단 간에 모두 유의한 차이가 있었으며, 공간적 청취에서는 일측 인공와우이 식 청년과 정상청력 청년 $(p=.000)$, 양측 인공와우이식 청년과 정상 청력 청년 $(p=.000)$ 간에 유의한 차이가 있었다(Figure 2). 집단과 듣기 항목에 따른 이차 상호작용 효과는 유의하지 않았다 $\left(F_{(4,84)}=\right.$ $.682, p=.249$, partial $\left.\eta^{2}=.031\right)$.

\section{인공와우이식 청년 관련 변수와 기능적 듣기 수행력과의 관련성}

인공와우이식 집단별로 단계적 중다회귀분석을 실시한 결과, 일 측 인공와우이식 청년 집단에서는 단음절단어 점수 $(\beta=.873, p=.017)$ 와 수용어휘 점수 $(\beta=-.692, p=.012)$ 가 일측 인공와우이식 청년의 K-SSQ 총점을 $55.7 \%$ (수정계수에 의하면 $43.6 \%$ ) 설명하는 것으로
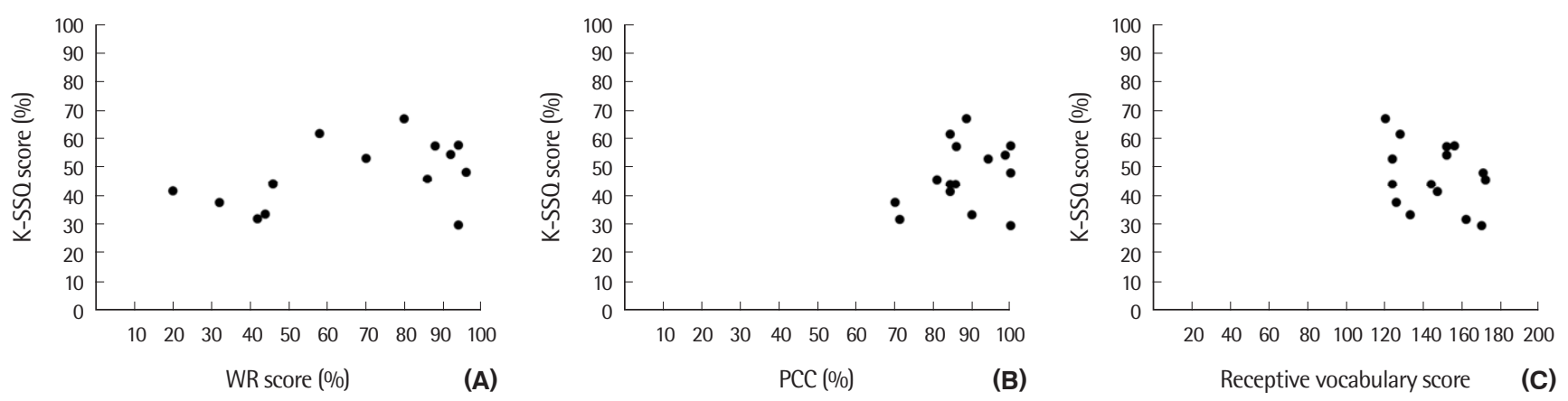

Figure 3. Scatterplot of the K-SSQ scores and the communication related to performance in adults with unilateral CI. (A) K-SSQ scores and WR scores in adults with unilateral Cl. (B) K-SSO scores and PCC in adults with unilateral Cl. (C) K-SSO scores and receptive vocabulary scores in adults with unilateral Cl.

$\mathrm{K}-\mathrm{SSQ}=$ Korean version of the Speech, Spatial and Qualities of Hearing Scale; $\mathrm{Cl}=$ cochlear implant; $\mathrm{WR}=$ word recognition; $\mathrm{PCC}=$ percentage of consonants correct.
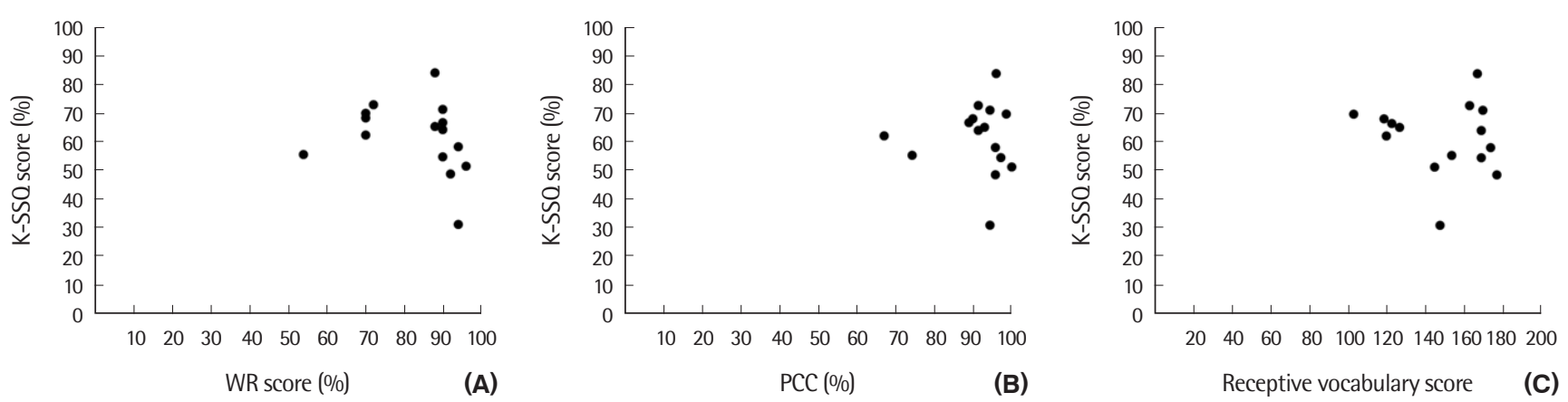

Figure 4. Scatterplot of the K-SSQ scores and the communication related to performance in adults with bilateral Cl. (A) K-SSQ scores and WR scores in adults with bilateral $\mathrm{Cl}$. (B) K-SSQ scores and PCC in adults with bilateral CI. (C) K-SSO scores and receptive vocabulary scores in adults with bilateral $\mathrm{Cl}$.

$\mathrm{K}$-SSO=Korean version of the Speech, Spatial and Qualities of Hearing Scale; $\mathrm{Cl}=$ cochlear implant; WR=word recognition; $\mathrm{PCC}=$ percentage of consonants correct. 
나타났다 $\left(F_{(3,14)}=4.606, p=.025, \mathrm{R}^{2}=.557\right.$ ) (Figure 3). 양측 인공와 우이식 청년 집단의 경우, $\mathrm{K}-\mathrm{SSQ}$ 의 총점을 유의하게 예측하는 변 수는 없는 것으로 나타났다(Figure 4).

\section{$\mathrm{K}-\mathrm{SSQ}$ 항목의 점수와 인공와우의 일측과 양측 착용 여부와의 관련성}

이항 로지스틱 회귀분석 모델에서 K-SSQ에서의 언어적 청취 점 수, 공간적 청취 점수, 음질 청취 점수를 독립변수로, 일측 인공와우 이식 청년과 양측 인공와우이식 청년 집단을 종속변수로 입력하였 다. 그 결과, 로지스틱 회귀분석 모델은 통계적으로 유의하였으며 $\left(\chi^{2}(1)=11.384, p=.016\right), \mathrm{K}-\mathrm{SSQ}$ 의 하위 항목 중 음질 청취 점수가 농 청년의 인공와우 양측 착용 여부를 유의하게 구분하는 것으로 나타났다(Wald's $\chi^{2}(1)=6.511, p=.001$, odds ratio=1.062). 즉, 음 질 청취 점수가 높을수록 양측 인공와우이식 청년으로 분류되었 으며 $(\beta=.060, p=.011)$, 분류 정확도는 $76.7 \%$ 로 나타났다.

\section{논의 및 결론}

본 연구에서는 청소년 혹은 청년기에 두 번째 인공와우이식을 시행받은 양측 인공와우이식 청년의 기능적인 듣기 수행력을 일측 인공와우이식 청년, 정상청력 청년과 비교함으로써, 양측 인공와 우이식이 농 청년의 기능적 듣기 수행력에 미치는 영향을 살펴보고 자 하였다. 그리고 일측과 양측 인공와우이식 청년의 기능적인 듣 기 수행력에 영향을 미치는 변수를 살펴보고, 기능적 듣기 수행력 검사의 듣기 항목 점수 중에서 일측 인공와우이식 청년과 양측 인 공와우이식 청년을 구분하는 유의한 변수가 있는지를 확인하였다.

일측 인공와우이식 청년, 양측 인공와우이식 청년, 정상청력 청 년의 K-SSQ 점수를 비교한 결과, 양측 인공와우이식 청년의 기능 적인 듣기 수행력이 일측 인공와우이식 청년보다는 유의하게 높았 지만, 정상청력 청년보다는 유의하게 낮았다. 이는 순차적 양측 인 공와우이식이 농 아동의 기능적 수행력에 긍정적인 영향을 미친다 고 보고한 선행연구(Kim et al., 2013; Kim et al., 2015)의 결과와 일 치한다. 그리고 농 성인을 대상으로 한 선행연구(Galvin et al., 2010; Noble et al., 2009)에서도 순차적으로 양측 인공와우이식을 받은 청년, 장년, 노년이 일측 인공와우이식 상태보다 양측 인공와우이 식 상태에서 기능적 듣기 수행력이 향상된 것으로 지각하는 것으 로 보고되었다. Noble 등(2009)이 청각장애 성인의 연령대에 따른 양측 인공와우이식의 효과를 자기 보고에 의한 듣기 능력의 측면 에서 살펴본 결과, 청년과 노년층 모두 양측 인공와우이식 상태에 서의 듣기 능력이 일측 인공와우이식 상태보다 향상된 것으로 나타
났다. Galvin 등(2010)이 일화보고서(anecdotal report)를 통해 양 측 인공와우이식 청년 9 명의 양측 인공와우이식 전과 후의 기능적 듣기 점수를 비교한 결과, 양측 인공와우이식 후에 기능적 듣기 점 수가 전반적으로 향상되었다. 이러한 연구 결과들은 비교적 늦은 시기에 두 번째 인공와우이식을 받더라도 양이 청취 이득을 일상 생활에서 지각할 수 있다는 것을 의미하며, 양측 인공와우이식의 이득이 연령대에 상관없이 청각장애인의 일상생활에서의 실제적 인 듣기 능력 향상에 긍정적인 영향을 미친다는 것을 시사한다.

$\mathrm{K}-\mathrm{SSQ}$ 검사에서 공간적 청취 항목의 점수가 언어적 청취와음질 청취 항목의 점수에 비해서 유의하게 낮았으며, 듣기 항목에 따른 집단 간 점수 패턴에서 차이를 보이지 않았다. 이는 일측과 양측 인 공와우이식 청년이 정상청력 청년과 동일하게 공간적 청취 항목에 서 듣기 능력이 다른 항목에 비해서 낮다고 인식하고 있음을 의미 한다. 인공와우이식 아동의 부모를 대상으로 일측과 양측 인공와 우이식 아동의 기능적 듣기 수행력에 관한 설문을 실시한 Kim 등 (2015)과 Kim 등(2013)의 연구에서도 공간적 청취 점수가 언어적 청취와 음질 청취의 점수에 비해서 낮은 경향을 보였다. 이러한 결 과는 공간적 청취 능력을 평가하는 문항의 특성이 관련되어 있을 것으로 생각된다. 공간적 청취는 음원의 거리감과 방향성을 판단 하는 듣기 능력으로, 청자가 특정 공간에서 움직이는 사물이나 사 람이 발생시키는 소리의 거리감(가깝다 vs. 멀다, 다가오고 있다 vs. 멀어지고 있다)과 방향성을 정확하게 인지하는 것을 말한다(Gatehouse \& Noble, 2004). K-SSQ에서 공간적 청취 항목의 문항을 살 펴보면, "귀하는 밖에 있습니다. 개가 크게 짖고 있다면 귀하는 쳐 다보지 않고 그 개가 어디 있는지 즉시 알 수 있습니까?”, “귀하는 거리에서 누군가의 목소리나 발소리로 그 사람이 얼마나 멀리 떨어 져 있는지 알 수 있습니까?” 등과 같이 청자가 예측할 수 없는 역동 적인 듣기 상황과 관련된 문항으로 주로 구성되어 있다. 반면에, 언 어적 청취(예: 귀하는 많은 사람이 말하고 있는 방에서 한 사람과 대화 중입니다. 귀하는 상대방이 말하는 것을 알아들을 수 있습니 까?)와음질 청취(예: 귀하가 라디오에서 음악이 흘러나오는 방에서 누군가와 말하고 있을 때 그 사람의 목소리를 음악과 구별해서 들 을 수 있습니까?) 항목의 문항은 주로 상대방과의 대화 상황, 말소 리와 환경음에 집중하는 상태에서의 기능적 듣기 능력을 판단하는 문항으로 구성되어 있다. K-SSQ의 항목에 따른 문항의 특성으로 인하여, 일측 인공와우이식 성인, 양측 인공와우이식 성인, 정상청 력 성인 집단에 상관없이 공간적 청취 점수가 언어적 청취와 음질 청취 점수에 비해서 낮게 나타난 것으로 판단된다.

본 연구에서 듣기 항목에 따른 집단 간차이를 살펴본 결과, 양측 인공와우이식 청년의 언어적 청취와 음질 청취 점수는 일측 인공 
와우이식 청년에 비해 유의하게 높았으나, 공간적 청취 점수에서는 일측 인공와우이식 청년보다 유의하게 높지 않았다. 이러한 결과는 늦은 시기에 두 번째 인공와우이식을 받은 청년의 경우 언어적 청 취와 음질 청취에 비해 공간적 청취의 이득이 상대적으로 적다고 해석할 수 있겠다. Kim 등(2015)의 연구에서는 순차적 양측 인공 와우이식 아동의 공간적 청취 점수가 일측 인공와우이식 아동에 비해서 유의하게 높았으며, 양측 인공와우이식 아동의 부모는 자녀 가 두 번째 인공와우이식을 한 후에 '마트 같은 장소에서 덜 두리번 거린다'와 같이 보고하여 공간적 청취와 관련하여 일상생활에서의 듣기 향상을 관찰할 수 있었다고 보고하였다. 그리고 Kim 등(2013) 은 언어적 청취, 공간적 청취, 음질 청취의 모든 항목에서 순차적 양 측 인공와우이식 아동의 점수가 일측 인공와우이식 아동보다 유의 하게 높았다고 보고하였다. 이처럼, 양측 인공와우이식 아동은 모 든 듣기 항목에서 일측 인공와우이식 아동보다 더 나은 수행력을 보였으나, 이보다 늦은 시기인 청소년기 혹은 청년기에 두 번째 인공 와우이식을 받은 청년은 일측 인공와우이식 청년보다 공간적 청취 에서 더 나은 수행력을 보이지 않았다. Kühn-Inacker 등(2004)은 양측 인공와우이식 아동 집단 내에서도 두 번째 인공와우이식의 시기가 늦어질 경우에 방향분별력에서 충분한 이득을 얻을 수 없 다고 보고한 바 있다. 본 연구와 선행연구 결과를 토대로 볼 때, 청소 년기와 청년기에 두 번째 인공와우이식을 받더라도 일상생활 듣기 활동에서 양이 청취의 이득을 얻을 수 있지만, 그 이득의 정도는 어 린 연령에 양측 인공와우이식을 시행받은 경우보다는 적을 수 있 다는 것을 알수 있다.

본 연구에서 일측 인공와우이식 청년과 양측 인공와우이식 청년 집단을 구분하여 단음절단어 점수, 자음정확도, 수용어휘 점수가 기능적 듣기 수행력에 미치는 영향을 살펴본 결과, 집단에 따라 기 능적 듣기 수행력을 예측하는 변수의 양상에 차이가 있었다. 일측 인공와우이식 청년 집단에서는 단음절단어 점수와 수용어휘 점수 가 기능적 듣기 수행력을 예측하는 유의한 변수였으며, 양측 인공 와우이식 청년 집단에서는 어떠한 변수도 기능적 듣기 수행력을 유 의하게 예측하지 않는 것으로 나타났다. 일측 인공와우이식 청년 집단만으로 살펴보면, 말지각과 어휘 지식이 일측 인공와우이식 청 년의 일상생활 듣기에 주요한 기능을 하고 있었다. 이는 인공와우 이식 청년의 의사소통 관련 삶의 질을 예측하는 중요한 변수가 말 지각이라고 보고한 선행연구(Kim \& Yoon, 2017; Lee, Jung, et al., 2018) 결과와 일치하는 것으로, 일측 인공와우이식 청년의 평가, 재 활, 상담 시에는 말지각 측면에서의 세심한 분석이 필요하다는 것 을 시사한다. 앞서 언급한 바와 같이, 중다회귀분석 결과에서 양측 인공와우이식 청년의 기능적 듣기 수행력을 유의하게 예측하는 변
수는 없는 것으로 나타났는데, 이는 투입 변수와 사용한 검사도구 의 특징에 기인한 것으로 보인다. 본 연구에서 인공와우이식 집단 간 동질성 검정에서 단음절단어 점수를 제외하고는 다른 변수에서 는 유의한 차이가 없었다는 점을 고려해 볼 때, 단음절단어 점수, 자음정확도, 수용어휘 점수가 양측 인공와우이식 청년의 기능적 듣기 수행력을 예측하기에는 민감하지 않은 변수였을 수도 있다. 인공와우이식 대상자의 수행력 예측 변수에 관한 선행연구(Bharadwaj, Maricle, Green, \& Allman, 2015; Lee, Sung, \& Sim, 2018) 에서는 임상에서 사용되고 있는 평가도구의 측정치가 문장 판단하 기나 문단 이해하기 등과 같은 종합적이고 높은 수준의 능력을 예 측하기에는 한계가 있다고 보고한 바 있다. 즉, 본 연구에서 사용한 K-SSQ 검사도구가 전반적이고 종합적인 듣기 수행력을 측정하기 때문에, 수행력 변수가 양측 인공와우이식으로 인한 양이 청취 이 득을 민감하게 예측하기에는 제한적이었을 수도 있을 것이다.

$\mathrm{K}-\mathrm{SSQ}$ 하위 항목인 언어 청취, 공간 청취, 음질 청취 중에서, 음 질 청취 점수가 일측 인공와우이식 청년과 양측 인공와우이식 청 년을 구분하는 유의한 변수였으며, 두 집단을 구분하는 정확도가 $76.7 \%$ 였다. 즉, 음질 청취 점수가 인공와우이식 청년의 양측 인공와 우착용 여부를 구분하는 변수여서, 음질 청취 점수가 높을수록 양 측 인공와우이식 청년으로 분류되는 경향을 보였다. 이러한 결과 는 양이 청취가 음질 청취에 미치는 영향과 관련된 것으로 생각된 다. 음질 청취는 동시에 들리는 여러 소리 중에서 소리의 분리 및 확 인, 소리의 명료도 및 자연스러운 정도, 듣기 노력과 관련된 능력으 로, 음악이나 환경음을 실감나게 들을 수 있게 하여 인간의 심미적 인 활동에 기여하는 것으로 알려져 있다(Gatehouse \& Noble, 2004). Tyler, Dunn, Witt와 Preece (2003)는 양이 청취를 통해서 얻을 수 있는 이득으로 일측만으로 청취하는 것보다 자연스러운 소리를 들 을 수 있고, 듣기에 필요한 인지 노력이 감소되며, 상대방과의 대화 에서 자신감이 생길 수 있다고 보고하였다. 이러한 결과를 토대로 볼 때, 일측 인공와우이식 청년이 양측 인공와우이식으로 양이 청 취가 가능해지면, 일측 인공와우만을 착용하였을 때보다 자연스럽 고 명료한 소리의 청취, 듣기 노력의 감소로 의사소통과 관련된 삶 의 질까지 향상이 가능할 것으로 생각된다.

본 연구를 통해서, 청소년기 혹은 청년기에 두 번째 인공와우이 식을 받더라도, 양측 인공와우이식으로 얻게 되는 양이 청취의 이 득이 일상생활 듣기 수행력에 긍정적인 영향을 미친다는 것을 확인 하였다. 듣기 항목별로 살펴보았을 때, 양측 인공와우이식 청년의 언어적 청취와 음질 청취 능력이 일측 인공와우이식 청년보다 유의 하게 높아서, 농 청년은 양측 인공와우이식을 통해 소음 조건에서 상대방의 말을 정확하게 듣고, 음악을 들을 때 분명하고 자연스럽 
게 들을 수 있는 등의 이점을 얻을 수 있었다. 일측 인공와우이식 청 년과 양측 인공와우이식 청년의 기능적 듣기 수행력을 유의하게 예 측하는 변수는 집단에 따라 양상이 달라서, 양이 청취 여부에 따라 일상생활에서의 실제적인 듣기 수행력에 영향을 미치는 변수에는 차이가 있음을 확인하였다. 또한, 양측 인공와우이식 청년의 기능 적 듣기 수행력을 유의하게 예측하는 수행력 관련 변수가 나타나지 않아서, 인공와우이식 성인의 기능적 듣기 수행력을 예측할 수 있 는 다양한 변수를 탐색할 필요가 있을 것으로 생각된다. 그리고 기 능적 듣기의 하위 항목 중에서 음질 청취 점수가 일측 인공와우이 식 청년과 양측 인공와우이식 청년을 구분하는 유의한 변수였으 며, 양측 인공와우이식 청년이 음질 청취와 관련된 소리 분리 및 확 인, 자연스러운 소리 청취, 듣기 노력 감소 등에서 일측 인공와우이 식 청년과 차별화되는 듣기 이득을 얻고 있는 것으로 나타났다. 본 연구에서는 비교적 늦은 시기에 두 번째 인공와우이식을 시행받은 선천성 농의 양측 인공와우이식 청년의 기능적 듣기 수행력을 분 석하였기 때문에, 연구결과를 청력손실 발생시기와 연령대가 다른 양측 인공와우이식 대상자에게 일반화하기에는 제한이 있다. 그러 므로, 향후 연구에서는 학령전기 및 학령기 아동, 청소년, 노인 등으 로 연령대를 확장하여, 양측 인공와우이식이 기능적 듣기 수행력 에 미치는 영향을 살펴볼 필요가 있겠다. 그리고 일측 인공와우이 식 청소년과 청년은 두 번째 인공와우이식 결정을 스스로 한다는 점을 고려하여, 이들의 결정을 위한 충분한 정보 제공, 평가, 상담, 재활에 도움이 되는 실제적인 듣기 능력을 측정하는 다양한 검사 도구 개발과 관련된 연구가 필요하다.

\section{REFERENCES}

Bharadwaj, S., Maricle, D., Green, L., \& Allman, T. (2015). Working memory, short-term memory and reading proficiency in school-age children with cochlear implants. International Journal of Pediatric Otorhinolaryngology, 79, 1647-1653.

Choi, Y. M., Kim, H. H., Jeong, S. W., \& Kim, L. S. (2017). Interpersonal competence in college students with cochlear implants: a preliminary study. Korean Journal of Otorhinolaryngology-Head and Neck Surgery, 61, 341348.

Cox, R. M., \& Alexander, G. C. (1995). The abbreviated profile of hearing aid benefit. Ear \& Hearing, 16, 176-186.

Cox, R. M., \& Alexander, G. C. (2002). The International Outcome Inventory for Hearing Aids (IOI-HA): psychometric properties of the English version. International Journal of Audiology, 41, 30-35.
Dillon, H., James, A., \& Ginis, J. (1997). Client Oriented Scale of Improvement (COSI) and its relationship to several other measures of benefit and satisfaction provided by hearing aids. Journal of the American Academy of Audiology, 8, 27-43.

Domviller-Lewis, C., Santa Maria, P. L., Upson, G., Chester-Browne, R., \& Atlas, M. D. (2015). Psychological Map stability in bilateral sequential cochlear implantation: comparing current audiology methods to a new statistical definition. Ear \& Hearing, 36, 497-504.

Galvin, K. L., Hughes, K. C., \& Mok, M. (2010). Can adolescents and young adults with prelingual hearing loss benefit from a second, sequential cochlear implant? International Journal of Audiology, 49, 368-377.

Galvin, K. L., \& Noble, W. (2013). Adaptation of the Speech, Spatial and Qualities of Hearing Scale for use with children, parents, and teachers. Cochlear Implants International, 14, 135-141.

Gatehouse, S., \& Noble, W. (2004). The Speech, Spatial and Qualities of Hearing Scale (SSQ). International Journal of Audiology, 43, 85-99.

Heo, M. J., \& Kim, L. S. (2010). School performance of children received cochlear implantation under age of five. Journal of Special Education: Theory and Practice, 11, 306-337.

Huh, M. J., \& Lee, D. (2009). A review of transitions to cochlear implants in Korea. Journal of Speech-Language \& Hearing Disorders, 18, 123-144.

Kim, B. J., An, Y. H., Choi, J. W., Park, M. K., Ahn, J. H., Lee, S. H., ... \& Han, G. C. (2017). Standardization for a Korean version of the Speech, Spatial and Qualities of Hearing Scale: study of validity and reliability. Korean Journal of Otorhinolaryngology-Head and Neck Surgery, 60, 279-294.

Kim, D. H., \& Yoon, M. S. (2017). Predicting the quality of communication life of university students with hearing loss. Communication Sciences \& Disorders, 22, 827-836.

Kim, J. S., Kim, L. S., \& Jeong, S. W. (2013). Functional benefits of sequential bilateral cochlear implantation in children with long inter-stage interval between two implants. International Journal of Pediatric Otorhinolaryngology, $77,162-169$.

Kim, M. J., Pae, S., \& Park, C. I. (2007). Assessment of Phonology and Articulation for Children (APAC). Incheon: Human Brain Research \& Consulting Co.

Kim, Y. J., Roh, J., Lee, J. J., Hong, S. A., Lim, H. J., Park, H. Y., \& Choung, Y. H. (2015). Functional listening performance of children with sequential bilateral cochlear implantation in daily life. Korean Journal of Otorhinolaryngology-Head and Neck Surgery, 58, 463-468.

Kim, Y. T., Hong, G. H., Kim, K. H., Jang, H. S., \& Lee, J. Y. (2009). Receptive 
and expressive Vocabulary test (REVT). Seoul: Seoul Community Rehabilitation Center.

Korea Ministry for Health, \& Welfare and Family Affairs. (2009). The criteria and methods of application of medical care. https://www.mohw.go.kr/react/ jb/sjb0406vw.jsp.

Kühn-Inacker, H., Shehata-Dieler, W., Müller, J., \& Helms, J. (2004). Bilateral cochlear implants: a way to optimize auditory perception abilities in deaf children? International Journal of Pediatric Otorhinolaryngology, 68, 12571266.

Lee, J. H., Cho, S. J., Kim, J. S., Jang, H. S., Lim, D. H., Lee, K. W., ... \& Kim, H. J. (2010). Korean Speech Audiometry (KSA). Seoul: Hakjisa.

Lee, S. G., Jung, S. I., Tark, P. K., Lee, S. B., \& Lee, Y. (2018). Quality of communication life in prelingually deafened adults with cochlear implants. Communication Sciences \& Disorders, 23, 528-538.

Lee, Y., \& Sim, H. (2015). Speech perception benefits of bilateral cochlear implantation for deaf children. Journal of Rehabilitation Research, 19, 175-193.

Lee, Y., Sung, J. E., \& Sim, H. S. (2018). Passive sentence comprehension difficulties and its related factors in children with cochlear implants. International Journal of Pediatric Otorhinolaryngology, 109, 60-66.

Long, Y., Liu, H., Li, Y., Jin, X., Zhou, Y., Li, J., ... \& Zhang, J. (2018). Early auditory skills development in Mandarin speaking children after bilateral cochlear implantation. International Journal of Pediatric Otorhinolaryngology, 114, 153-158.
Noble, W., Tyler, R. S., Dunn, C., \& Bhullar, N. (2009). Younger- and olderage adults with unilateral and bilateral cochlear implants: speech and spatial hearing self-rating and performance. Otology \& Neurotology, 30, 921929.

Nopp, P., Schleich, P., \& D’Haese, P. (2004). Sound localization in bilateral users of MED-EL COMBI 40/40+ cochlear implants. Ear \& Hearing, 25, 205214.

Papsin, B. C., \& Gordon, K. A. (2008). Bilateral cochlear implants should be the standard for children with bilateral sensorineural deafness. Current Opinion in Otolaryngology \& Head and Neck Surgery, 16, 69-74.

Santarelli, R., De Filippi, R., Genovese, E., \& Arslan, E. (2008). Cochlear implantation outcome in prelingually deafened young adults. Audiology \& Neurotology, 13, 257-265.

Strøm-Roum, H., Laurent, C., \& Wie, O. B. (2012). Comparison of bilateral and unilateral cochlear implants in children with sequential surgery. International Journal of Pediatric Otorhinolaryngology, 76, 95-99.

Tyler, R. S., Dunn, C. C., Witt, S. A., \& Noble, W. G. (2007). Speech perception and localization with adults with bilateral sequential cochlear implants. Ear \& Hearing, 28, 86-90.

Tyler, R. S., Dunn, C. C., Witt, S. A., \& Preece, J. P. (2003). Update on bilateral cochlear implantation. Current Opinion in Otolaryngology \& Head and Neck Surgery, 11, 388-393. 
Appendix 1. Items of the Speech, Spatial and Qualities of Hearing Scale

모든 질문들은 귀하의 일상생완 강험과 관련 있으리라 기대하지만, 만약 질문이 귀하에계 직용되지 않는 상황을 므사 한다면, '해당 없음에 표시해 주시기 바갆니다. 또한 예 퀴하에게 해당되지 않는지 질문 잎에 직어 주십시오.

\section{(Part 1: 언어적 청취 평가)}

1. 귀하는 한 사람과 말하고 있고 갈은 방에 TV가 커저 있습니다. TV 소리믈 줄이지 않고 상대망이 말하는 것을 알아들을 수 있습니께?

2. 퀴하는 카페드가 깔린 조용한 방에서 한 사람과 대화 하고 있습니다. 그 사람이 말하는 깃을 알아늘을 수 있 습니께?

3. 퀴하믈 쪼함하여 5명의 사람들과 다자에 둠러앉아 있 고, 주빈은 조용합니다. 모두를 볼 수 있는 상황에서 귀 하는 대화들 따라갈 수 있습니까?

4. 퀴하를 포함하여 5 명의 사람들과 붐비는 식당에 있습 니다. 모두를 볼 수 있는 상황에서 퀴하는 대화를 따라 갈 수 있습니까?

5. 귀하는 한 사람과 대화하고 있고, 환쭝기나 물이 흐르 는 소리 같은 지속저인 배경 소음이 있습니다. 퀴하는 상 대방이 발하는 것을 알아들을 수 있습니까?

6. 퀴하를 포함하여 5 명의 사람들과 붐비는 식당에 있습 니다. 모두를 볼 수는 없을 때 귀하는 대화를 따라갈 수 있습니까?

7. 귀하는 교외나 서울역 건물 같은, 울림이 많은 장소에 서 누군가와 대화하고 있습니다. 귀하는 상대방이 발하 는 것을 알아들을 수 있습니까?

8. 퀴하는 어떤 사람과 대화 중에 그 사람과 같은 굲기 (톤)의 목소리를 가진 다른 사람이 말을 해도 상대방과 대화률 나홀 수 있습니까?

9. 귀하는 어뗜 사람과 대화 중에 그 사람과 다른 굵기 (톤)의 목소리를 가진 사람이 말을 혜도 상대방과 대화 를 나눌 수 있습니까?
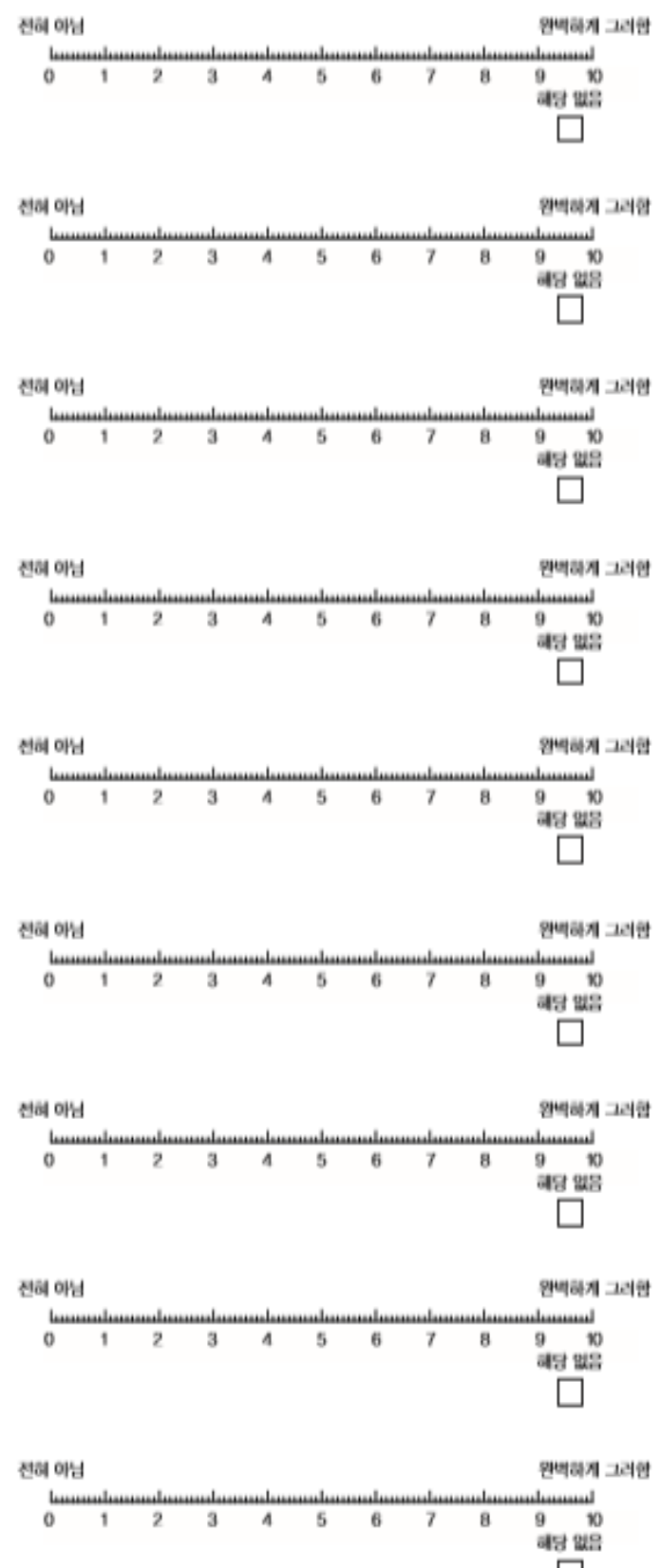

(Continued to the next page) 
Appendix 1. Continued

10. 귀하는 TV 뉴스를 보먼서 통시에 누군가의 말을 든 고 있습니다. 귀하는 양측의 말을 모두 알아들을 수 있습 니까?

11, 귀하는 많은 사람이 발하고 있는 방에서 한 사람과 대화 중입니다. 퀴하는 상대방이 말하는 깃을 알아들을 수 있습니깨?

12. 귀하는 그릅 안에서 서로 돌이가머 대화하고 있습니 다. 세로운 사잠이 말을 할 때 시작부터 놓치지 않고 쇰 계 따라갈 수 있습니깨?

13. 귀하는 전화로 쉼계 대화를 할 수 있습니까?

14. 귀하는 전화로 누군가의 말을 들고 있고 있에 있는 사람이 말을 결기 시작함니다. 귀하는 양측의 말을 모두 알아들을 수 있습니께?

\section{(Part 2: 공간적 청취 평가)}

1. 귀하는 익숙하지 않은 야외에 있습니다. 누군가 기계 로 잔디 짞는 소리가 들리지만 그 모슴을 볼 수 잆습니 다. 귀하는 소리가 어디서 나는지 바로 알 수 있습니께?

2. 귀하는 여러 사람과 다자에 둘러앉아 있거나 모임을 하 고 있고 모두를 볼 수는 없습니다. 누군가 말하기 시작하 자 마자 퀴하는 그 사람이 어디 있는지 알 수 있습니끼?

3. 귀하는 두 사람 사이에 앖아 있습니다. 그들 중 한 사 람이 말하기 시작할 때 귀하는 처다보지 않고 그 사람이 오른쪽에 있는지 원쪽에 있는지 바로 알 수 있습니까?

4. 퀴하는 익숙하지 않은 집에 있습니다. 조용한 가운데 문이 쾅 닫히는 소리를 들으면 퀴하는 그 소리가 어디서 넜는지 바로 알 수 있습니께?

5. 귀하는 건물의 위아래 층 사이 계단에 있습니다. 다른 층에서 나는 소리들을 들는다면 귀하는 그 소리가 어디 서 나는지 윔계 알 수 있습니께?
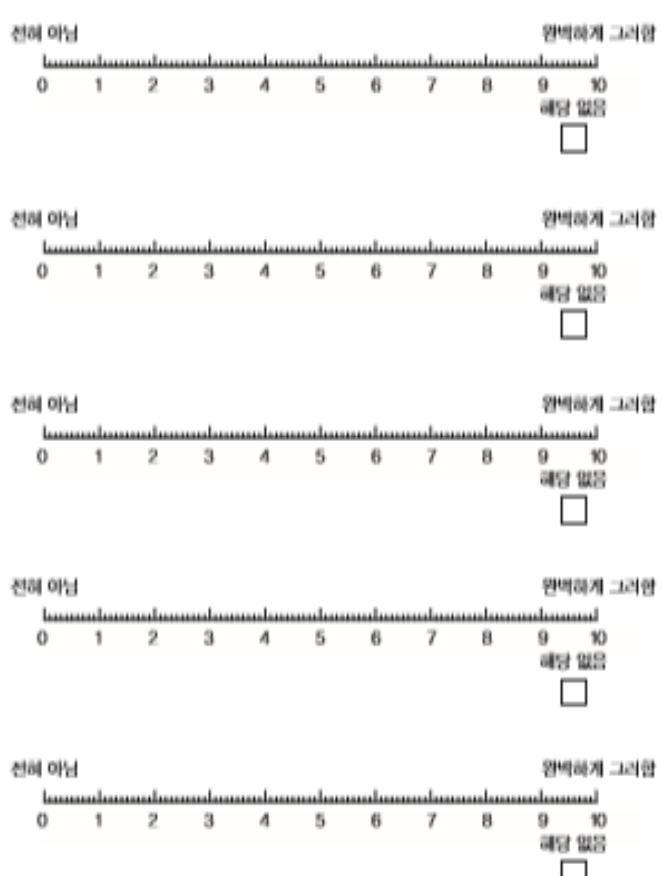

ํㅗㅇ
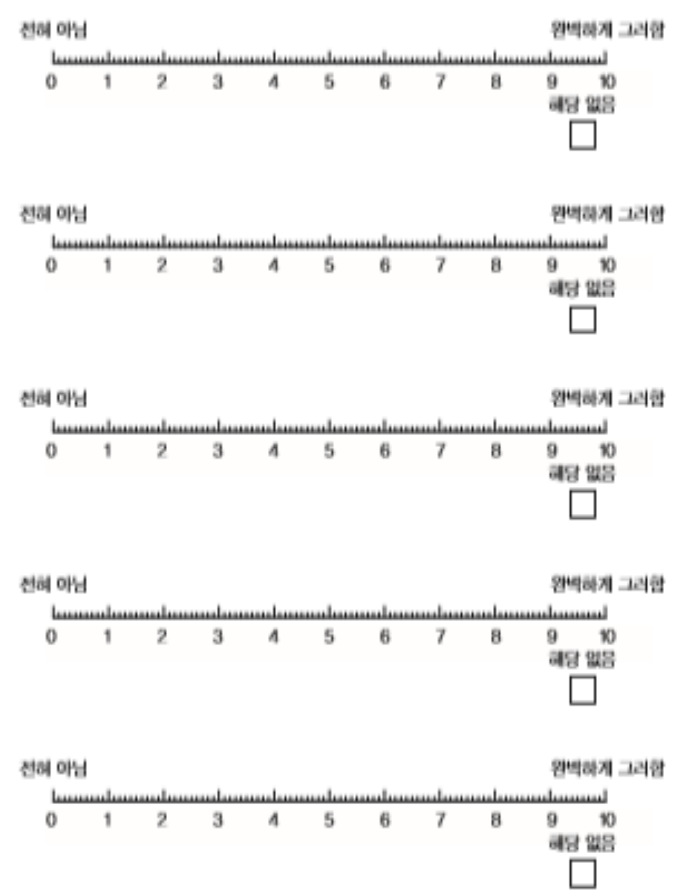

(Continued to the next page) 
Appendix 1. Continued

6. 퀴하는 밖에 있습니다. 개가 크계 짓고 있다민 퀴하는 처다보지 않고 그 개가 어디 있는지 즉시 알 수 있숩니깨?

7. 퀴하는 봄비는 거리의 보행로에 서 있습니다. 귀하는 비 스나 드리이 어느 방향에서 오는지 보기 진에 든고 바로 알 수 있습니깨?

8. 귀하는 기리에서 누군가의 목소리나 발소리로 그 사람 이 얼마나 밀리 밀어저 있는지 알 수 있습니께?

9. 귀하는 비스나 드럭의 소리로 그것듬이 얼마나 별리 멸어지 있는지 판단할 수 있습니께?

10. 귀하는 버스나 트럭의 소리만 들고 어느 빙향으로 이 동 중인지 알 수 있습니깨? (에: 귀하의 원쪽에서 오른쪽 으로 또는 오른쪽에서 왼쭉으로)

11. 귀하는 어떤 사람의 목소리나 발소리만 든고 그 사람 이 어느 방향으로 이통 중인지 알 수 있습니께? (에: 귀하 의 왼쪽에서 오른쪽으로 또는 오른쪽에서 왼쪽으로)

12. 귀하는 목소리나 발소리로 그 사람이 귀하를 향해서 다가오는지 밀어지 가는지믈 알 수 있숩니까?

13. 퀴하는 소리로 버스나 트릭이 퀴하를 향해서 다가오 는지 멀어저 가는지를 알 수 있습니끼?

14. 귀하는 소리를 들을 때 명황히 외부에서 들린다기보 다 귀하의 머릿속에서 맴도는 것처럼 들렙니끼?

15. 퀴하가 볼 수 없고 들을 수만 있는 사람 또는 물건의 소리를 들고 실제로 보게 되번 예상했민 것보다 더 가까 이 있숩니까?

16. 귀하가 볼 수 없고 들을 수만 있는 사람 또는 물건의 소리를 들고 실제로 보게 되면 예상했던 것보다 더 밀리 있습니까?
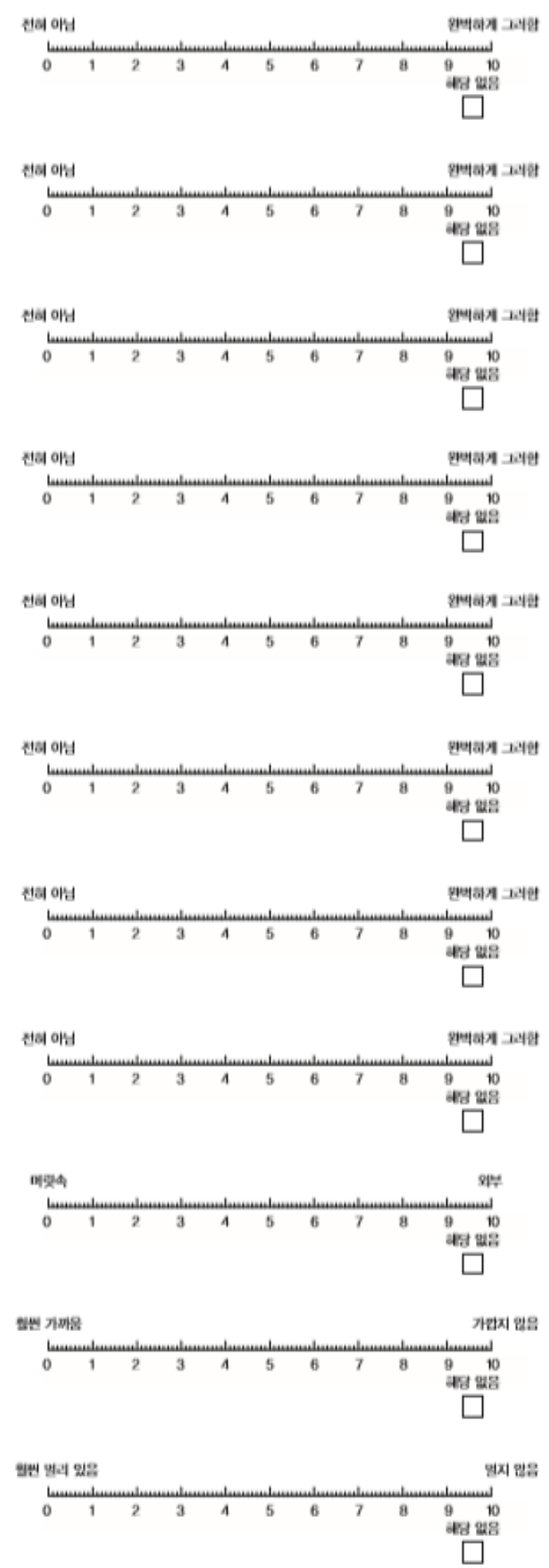

(Continued to the next page) 
Appendix 1. Continued

17. 귀하는 소리가 나는 쿳이라고 예상되는 위치를 정 화히 예측할 수 있슌니까?

\section{(Part 3: 음질 청취 평가)}

1. 퀴하는 두 가지 소리를 한찌번에 들을 때 각각의 소리 를 구분할 수 있습니께? (에: 라디오 소리와 물 봇는 소리 가 동시에 들렬 때)

2. 퀴하는 두 가지 이상의 소리를 동시에 들을 빼 하나의 합치진 소리로 흠컵니까?

3. 귀하가 라디오에서 음악이 흘러나오는 방에서 누군가 와 말하고 있을 매 그 사람의 목소리를 음악과 구별해서 들을 수 있습니께?

4. 귀하는 사람들을 각자의 목소리로 쉼게 알 수 있습 니까?

5. 귀하는 친숙한 음악 작품들을 서로 쉬게 구별할 수 있 습니까?

6. 퀴하는 소리들 간의 차이를 구분할 수 있습니까? (예: 자동차와 비스 소리, 빔비에서 물 꼻는 소리와 프라이펜 에서 음식을 요리하는 소리)

7. 귀하는 음악을 들을 때 어뗜 악기로 연주하는지 알아 들을 수 있숩니께?

8. 귀하는 음악을 들을 때 분평하고 자연스렵게 들립니 까?

9. 귀하는 흔히 접하는 일상생환의 소리들이 분명하게 들 립니까?
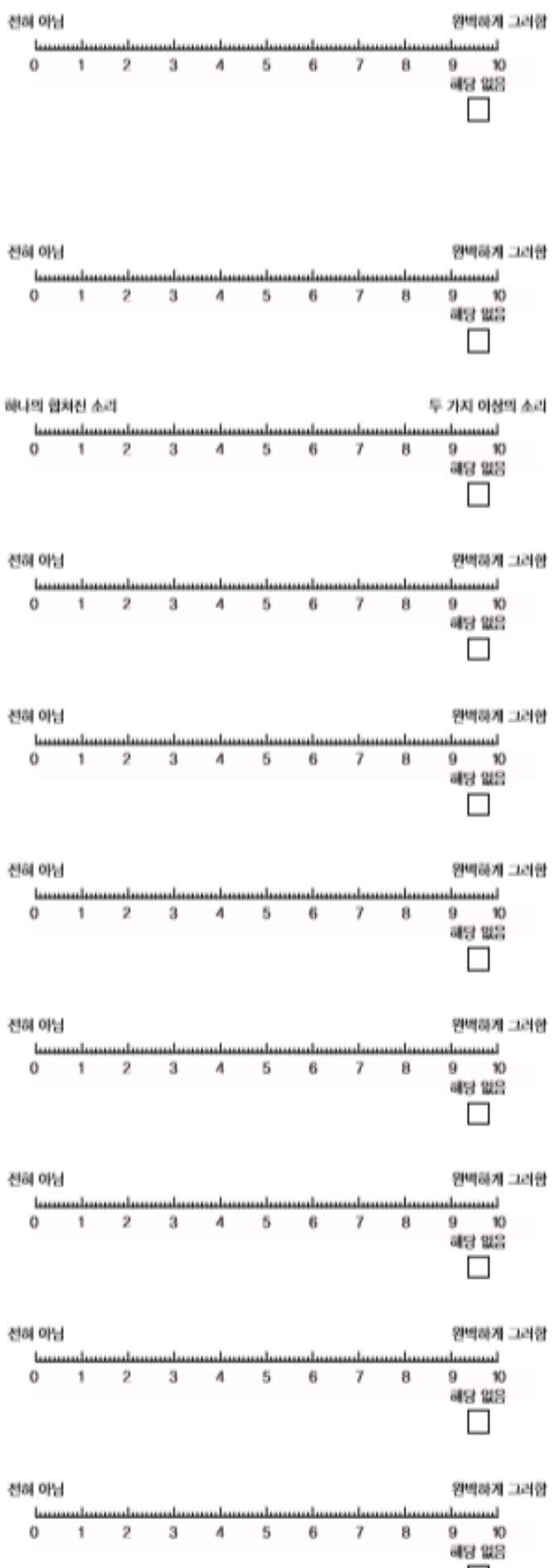
Appendix 1. Continued

10. 귀하는 다른 사함들의 복소리가 분명하고 자인스퀴 계 들거니깨?

11. 퀴히가 들는 일상생왈 소리늘이 부자연스립습니께?

12. 귀하 본인의 목소리가 사연스버계 들럽니까?

13. 귀하는 사함듬의 꼭소리로 그듬의 기분을 쉬게 판단 핞 수 있습니까?

14. 퀴하는 누군가의 말을 든거나 무잇인가를 들을 때 곙 장히 집종해야만 합니께?

15. 귀하는 다른 사람들과 대화할 때 알아들기 위혜서 많은 노려을 가울여야 합니께?

16. 귀하가 원전합 때 잎 사람이 밥하는 것을 쉼게 알아 들을 수 있습니께?

17. 퀴하가 조수석에 앉아 있을 때 운전자가 말하는 것을 쉬계 알아늘을 수 있습니께?

18. 귀하는 무엿인가를 들으려고 에쓸 매 그 소리 외에 다른 소리들은 쉼게 무시핲 수 있습니까?
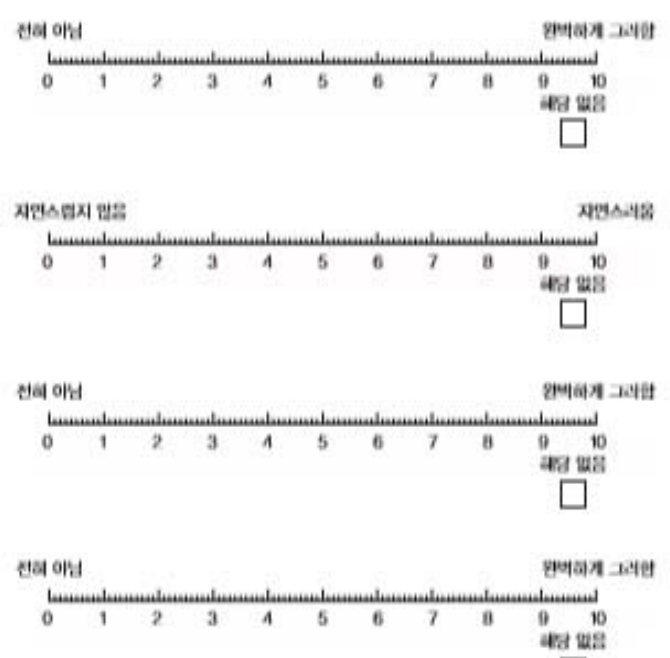

$\square$
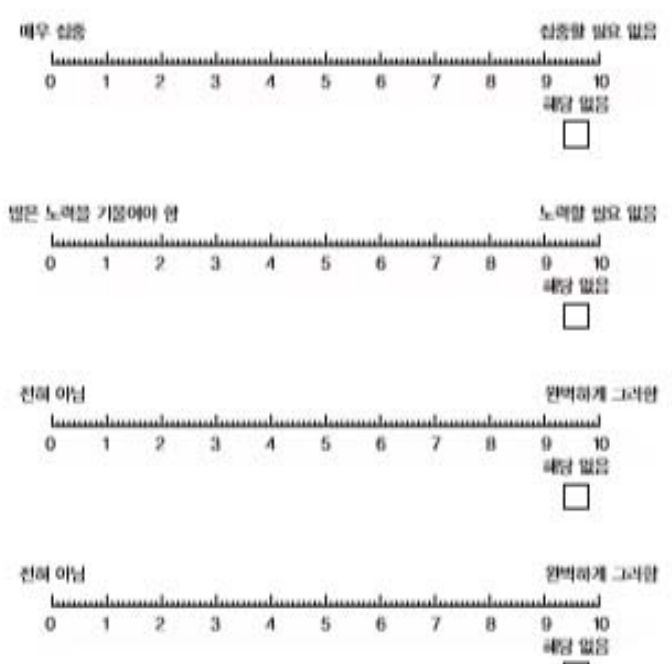

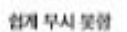

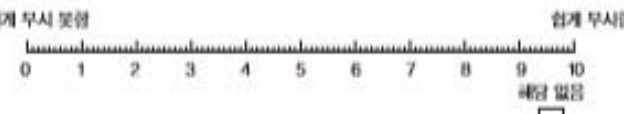




\section{국문초록}

\section{순차적 양측 인공와우이식 청년의 기능적인 듣기 수행력 이영미(교수, 제1저자, 교신저자) \\ 동명대학교 언어치료학과}

배경 및 목적: 본 연구에서는 순차적으로 양측 인공와우이식을 받은 선천성 농 청년, 일측 인공와우이식 청년, 정상청력 청년의 기능적 인 듣기 수행력을 비교하고, 인공와우이식 청년의 각 집단에서 기능적 듣기 수행력을 예측하는 유의한 변수를 탐색하며, 기능적 듣기 수행력의 하위 영역 중에서 양측과 일측 인공와우이식 청년을 구분하는 유의한 변수를 살펴보고자 하였다. 방법: 생활연령이 만 18-28 세인 양측 인공와우이식 청년(15명), 일측 인공와우이식 청년(15명), 정상청력 청년(15명)을 대상으로 기능적 듣기 수행력을 평가하였 다. 기능적 듣기 수행력은 한국어판 언어공간음질청취평가(The Korean version of the Speech, Spatial and Qualities of Hearing Scale, $\mathrm{K}-\mathrm{SSQ}$ )를 이용하여 평가를 하였다. 결과: 양측 인공와우이식 청년의 기능적인 듣기 수행력은 K-SSQ의 세 항목(언어 청취, 공간 청취, 음질 청취)에서 모두 일측 인공와우이식 청년보다 유의하게 높았지만, 정상청력 청년보다는 유의하게 낮았다. 단음절단어 점수와 수용 어휘 점수가 일측 인공와우이식 청년의 기능적 듣기 수행력을 유의하게 예측하는 변수였으며, K-SSQ의 세 항목 중에서 음질 청취 점수 가 양측과 일측 인공와우이식 청년을 구분하는 유의한 변수였다. 논의 및 결론: 두 번째 인공와우이식을 늦은 시기에 받더라도 순차적 양측 인공와우이식 청년이 일측 인공와우이식 청년보다 더 나은 기능적 듣기 수행력을 성취할 수 있었다.

핵심어: 기능적인 듣기 수행력, 순차적 양측 인공와우이식, 선천성 농, 청년

본 연구는 2018학년도 동명대학교 교내학술연구비 지원에 의하여 연구되었음(No. 2018F063).

\section{참고문헌}

김다혜, 윤미선(2017). 청각장애 대학생의 의사소통 삶의 질 예측변인. Communication Sciences \& Disorders, 22, 827-836.

김민정, 배소영, 박창일(2007). 아동용 발음평가(APAC). 인천: 휴브알앤씨.

김봉직, 안용휘, 최진웅, 박무균, 안중호, 이승환, 박경호 등(2017). 한국어판 The Speech, Spatial and Qualities of Hearing Scale의 표준화: 타당도 및

신뢰도 연구. 대한이비인후과학회지 두경부외과학, 60,279-294.

김영태, 홍경훈, 김경희, 장혜성, 이주연(2009). 수용·표현어휘력검사(REVT). 서울: 서울장애인복지관.

김유정, 노지민, 이종주, 홍수아, 임혜진, 박헌이, 정연훈(2015). 순차적 양측 인공와우 아동들의 일상생활에서의 기능적 듣기수행력. 대한이비인후과

학회지 두경부외과학, 58, 463-468.

보건복지가족부(2009). 요양급여의 적용기준 및 방법에 관한 세부사항 고시개정. https://www.mohw.go.kr/react/jb/sjb0406vw.jsp.

이슬기, 정상임, 탁평곤, 이수복, 이영미(2018). 인공와우이식 선천성 농 성인의 의사소통 관련 삶의 질. Communication Sciences \& Disorders, 23,

528-538.

이영미, 심현섭(2015). 양측 인공와우이식이 청각장애 아동의 말지각에 미치는 영향. 재활복지, 19, 175-193.

이정학, 조수진, 김수진, 장현숙, 임덕환, 이경원, 김형종(2010). 어음청각검사(Korean Speech Audiometry, KSA). 서울: 학지사.

최영미, 김희화, 정성욱, 김리석(2017). 인공와우이식 대학생의 대인관계 유능성. 대한이비인후과학회지 두경부외과학, 61, 341-348.

허명진, 이드보라(2009). 국내 인공와우 이식 변천에 대한 소고. 언어치료연구, 18, 123-144.

허민정, 김리석(2010). 인공와우이식 아동의 학교 수행력: 5세 이전에 수술 받은 아동을 중심으로. 특수교육저널: 이론과 실전, 11, 306-337.

허지혜, 이재희(2009). 인공와우와 보청기 양이착용이 K-HINT 수행도에 미치는 혜택. 청능재활, 5, 60-70. 